\title{
Assessing Espoused Goals in Private Family Firms Using Content Analysis
}

\author{
Aaron F. McKenny', Jeremy C. Short', Miles A. Zachary², \\ and G.Tyge Payne ${ }^{2}$
}

\begin{abstract}
Understanding how private family firms gauge performance is of great interest to family business scholars. Unfortunately, finding comparable data to understand differences in the performance of such firms is challenging. This study draws from the organizational identity literature to show how private family firms communicate different goals in publicly available organizational narratives. The authors illustrate a process using content analysis that allows family business scholars to create a comparative data set that captures both normative and utilitarian goals using website and press release narratives from a sample of Australian firms.
\end{abstract}

\section{Keywords}

content analysis, identity, narrative

Helping family businesses accomplish their goals and improve their performance is a cornerstone of family business research (Chua, Chrisman, \& Sharma, 1999). However, measuring the performance of private firms has long been a challenge for management researchers (Dess \& Robinson, 1984). Owners of privately held businesses are often disinclined to divulge "sensitive" information to outsiders. If they do share this information, it is possible that the company may not follow standardized accounting procedures, rendering the data incomparable to those of other companies (Dess \& Robinson, 1984). Furthermore, research has found that being a family business can lead firms to engage in unique accounting practices as well (e.g., Salvato \& Moores, 2010). Alternative approaches to gathering performance data such as surveys are often criticized for their subjectivity and resulting limitations, such as nonresponse bias and common-method variance, which can threaten the validity of findings (Wall et al., 2004).

The family business setting magnifies this challenge. Family businesses are likely to pursue family-related goals in addition to the business-related goals commonly assessed by business researchers, while hoping to perform well in both dimensions (Basco \& Pérez Rodriguez, 2009; Sorenson, 1999). As a result, researchers ignoring either type of goal may glean only limited insight into family firm behavior (Chrisman, Kellermanns, Chan, \& Liano, 2010). Family businesses are also likely to have multiple salient goals that are driven by the values of the family and to change these goals over time (Sharma, Chrisman, \& Chua, 1997; Sorenson, Goodpaster, Hedberg, $\& \mathrm{Yu}, 2009)$. Thus, it would be inappropriate to approach a sample of private family firms with a single measure of performance without first identifying whether that measure is important to the firms in the sample.

Addressing this methodological challenge, we present an organizational identity-based method with which researchers can assess the salient goals of private family firms by identifying each firm's espoused goals. Organizational identity refers to the central and enduring aspects of a firm that separates it from other, similar firms (Albert \& Whetten, 1985). Such a perspective is attractive for the study of family business because

\footnotetext{
'University of Oklahoma, Norman, OK, USA

${ }^{2}$ Texas Tech University, Lubbock, TX, USA
}

Corresponding Author:

Jeremy C. Short, University of Oklahoma, 660 Parrington Oval, Norman, OK 73019-0390, USA

Email: jeremy.short@ou.edu 
members of these organizations identify with both the utilitarian (business) and normative (family) identities of the organization (Ashforth \& Mael, 1989; Foreman \& Whetten, 2002). A utilitarian identity might be reflected by a focus on profit maximizing goals including sales, profit, and growth. A firm's normative identity would be reflected by an interest in noneconomic goals, such as a focus on family legacy, environmental sustainability, or socioemotional wealth (e.g., Gómez-Mejía, Haynes, Núñez-Nickel, Jacobson, \& Moyano-Fuentes, 2007; Gómez-Mejía, Makri, \& Larraza Kintana, 2010).

We illustrate the use of content analysis as a methodological technique with which to capture the espoused goals of private family firms. Content analysis is a useful method to ascertain the cognitive comparators and performance goals that managers project to numerous organizational stakeholders. For example, Short and Palmer (2003) used content analysis to identify organizational performance referents in a sample of 119 publicly traded restaurants. Palmer and Short (2008) used content analysis of business school mission statements to examine expressions of commitment to survival, growth, and profitability. More recently, content analysis has been applied to mission statements to capture comparable measures, including elements related to organizational performance, in social ventures (Moss, Short, Payne, \& Lumpkin, 2011).

Despite the promise of content analysis to identify differences in the espoused goals of family businesses, research examining the goals of privately held family businesses has yet to use these techniques. In this article, we examine how private family firms' identities are reflected through their espoused goals in organizational narratives. In particular, we present a procedure that can be followed by family business scholars to create comparable data concerning the relative salience of private family firm goals. In doing so, we make two key contributions to the family business literature. First, this study is the first to introduce a content analytic process by which the salient goals of private family businesses can be gathered and assessed from publicly available organizational narratives (e.g., websites, press releases). Given the difficulty of collecting performance data on these businesses and family businesses' propensity to have multiple goals that change over time, understanding the salient goals of a sample of private family firms before attempting to measure their performance is key. Second, we provide the first demonstration of how DICTION, a computer-aided content analysis tool, can complement the manual content analytic process to study the use of language in private family firms' organizational narratives. In sum, this article presents a novel method with which to understand differences in the espoused goals of private family firms in the narratives they commonly use to project such goals.

\section{Assessing the Espoused Goals of Private Family Firms}

In this study, our phenomena of interest are espoused goals (Crane, 2000; Roth \& Ricks, 1994). We define espoused goals as the desired economic or noneconomic outcomes of an organization as communicated to stakeholders via organizational narratives. To clarify this definition, we contrast espoused goals with two related phenomena: performance outcomes and operative goals. Performance outcomes measure the organization's progress against some financial, product market, or shareholder return target (Richard, Devinney, Yip, \& Johnson, 2009). This construct differs from espoused goals in several ways. First, performance outcomes suggest accomplishment rather than intention or aspiration. Second, performance focuses on financial, product market, and/or shareholder return outcomes where espoused goals could look at areas outside of these, such as social impact. Third, the dimensions with which one assesses the performance outcomes of a firm need not be a salient metric to the firm itself. Finally, performance outcomes do not need to be communicated via organizational narratives, whereas espoused goals do. Operant goals, on the other hand, may be defined as the desired outcomes of an organization as evidenced through the organizations policies and actions (Perrow, 1961). Although the scope of this definition is sufficiently broad to include noneconomic outcomes, it requires a priori knowledge of organizational processes to measure and does not specify that the organization needs to communicate these goals.

The organizational identity literature provides a valuable lens with which to examine the espoused goals of private family firms. Organizational identity is defined as the core characteristics of an organization that are central and enduring and that distinguish it from other similar organizations (Albert \& Whetten, 1985). These identities guide the sense- and decision-making rules that are deemed acceptable for members of the organization 
(Dutton \& Dukerich, 1991) and have been suggested to be key in the ongoing success of the organization (Barney et al., 1998).

Content analysis provides a valuable way with which to capture the espoused goals that are reflected in private family firms' identities. Content analysis is a method by which a text is classified or categorized by following a predetermined set of procedures (Weber, 1990). For example, Short and Palmer (2003) use content analysis to examine performance comparators in publicly traded firms by looking at shareholder letters. Although private family firms are not required to provide shareholder letters, these firms do produce a number of relevant documents that previous research has used for content analysis, including websites (Jose \& Lee, 2007; Lamertz, Heugens, \& Calmet, 2005; Micelotta \& Raynard, 2011), press releases (Froehlich \& Rüdiger, 2006; Henry, 2006), mission statements (O'Gorman \& Doran, 1999; Pearce \& David, 1987), and e-mails (Jun \& Cai, 2001).

In the following sections, we present arguments suggesting that the key goals of private family firms can be captured in available organizational narratives. Because family firms have hybrid identities that should reflect both economic and noneconomic goals (Sharma et al., 1997; Tompkins, 2010), we argue that both normative and utilitarian goals will be reflected in the organizational narratives of private family firms.

\section{Utilitarian Identity}

A utilitarian identity relates to the economic productionoriented goals of the firm (Albert \& Whetten, 1985). Specifically, the utilitarian identity shared by for-profit businesses drives them to pursue the profit-maximizing, economic goals. Thus, the utilitarian identity of for-profit family businesses accounts for economic goals commonly pursued by family businesses (e.g., "make profits now"; Tagiuri \& Davis, 1992). Indeed, several studies have indicated that private family firms pursue utilitarian goals (Murphy, 2005; Stockmans, Lybaert, \& Voordeckers, 2010).

The importance of utilitarian goals to private family firms is a function of their salient stakeholders. Family businesses have a broad array of stakeholders, ranging from founders and nonfamily employees within the firm to suppliers and society outside the firm (Freeman, 1984; Sharma, 2004; Zellweger \& Nason, 2008). Some of these stakeholders have a vested interest in the financial performance of the company but are not affected by the pursuit of noneconomic goals. For example, nonfamily employees are important stakeholders to the family business (Chrisman, Chua, \& Sharma, 1998; Chua, Chrisman, \& Sharma, 2003). However, if these employees perceive that the controlling owners of the business are pursuing family-related goals that deteriorate the long-term economic performance of the firm, they may become dissatisfied, underperform, or leave the company (Lubatkin, Ling, \& Schulze, 2003). In short, neglecting to convey the economic goals of the family business to stakeholders who primarily value these economic goals may cause conflict in the relationship and potentially lead them to disengage with the firm (Astrachan \& McMillan, 2003; Sharma, 2004).

Because organizational narratives are one way in which family businesses convey their identities to stakeholders, they are incented by salient, nonfamily stakeholders to convey some aspects of their utilitarian identity in these communications. Communicating the economic goals of the organization stemming from their utilitarian identities is one way of doing so. Two commonly discussed utilitarian goals investigated in the family business literature include revenue/sales and net profit (Lee, 2006; McConaughy, \& Phillips, 1999; Morris, Williams, Allen, \& Avila, 1997). We would expect that these goals would be found in organizational narratives created by private family businesses. Stated formally, we ask the following:

Research Question 1: Do private family firms discuss utilitarian goals in their organizational narratives?

\section{Normative Identity}

A firm's normative identity is based on symbols and traditions (Albert \& Whetten, 1985). The normative identity drives many idiosyncrasies in otherwise economic organizations. In family businesses, this is the family identity of the organization that accounts for many noneconomic goals seen in family businesses (e.g., "Achieve financial security for the owner(s) family in the future"; Tagiuri \& Davis, 1992).

Some stakeholders associated with private family firms use particularistic decision criteria that would result in a focus on normative goals in addition to their utilitarian goals (Carney, 2005). Principal among these 
Table I. Content Analytic Steps for Measuring Espoused Goals in Private Family Firms

I. Identify the research question, theory, and organizing framework for the study

2. Identify a sample of private family firms

3. Select organizational narratives for collection

4. Collect the organizational narratives

5. Read organizational narratives, identifying and tabulating references to goals

6. Identify a classification scheme and categorize espoused goals

7. Conduct appropriate statistical analyses
I. Do private family firms assess their performance by articulating utilitarian and normative goals?

2. Identified Australia's top 100 private family firms

3. Selected press releases/news postings and "about us" sections of corporate websites

4. Collected I 63 press releases/news postings and 77 "about us" website sections

5. Identified 28 espoused goals: I 3 normative, I 5 utilitarian (see Tables 2, 3, 4, and 5)

6. Tagiuri and Davis's (1992) family business goals, financial vs. operational (Venkatraman \& Ramanujam, 1986)

7. Conducted one-sample $t$ tests to test our two hypotheses:

i. Private family firms discuss utilitarian goals in their organizational narratives

ii. Private family firms discuss normative goals in their organizational narratives stakeholders are individuals (and particularly employees) with family ties, making them particularly salient to family businesses (Carlock \& Ward, 2001). Stakeholders affiliated with the founding family may value being a responsible corporate citizen because such activities may bolster the family and family business name and reputation in the community (Dyer \& Whetten, 2006).

Family businesses are incented to demonstrate the business' commitment to the normative identity of the organization to ensure that these internal and external stakeholders' buy-in into the business. To do so, family businesses may incorporate the noneconomic goals associated with the normative identity of the organization in their organizational narratives. Recent studies looking at normative goals of family businesses have looked at corporate social performance (Dyer \& Whetten, 2006), satisfaction with succession processes (Sharma, Chrisman, Pablo, \& Chua, 2001), and the functional integrity of the family (Olson et al., 2003). Stated formally, we pose the following:

Research Question 2: Do private family firms discuss normative goals in organizational narratives?

\section{Measuring Espoused Goals in Private Family Firms}

To develop a process with which to analyze the espoused goals of private family firms, we use a content analytic approach adapted from Neuendorf's (2002) seminal content analysis text. In conjunction with presenting our recommended procedures, we provide an illustrative analysis using organizational narratives of private family firms to demonstrate how content analysis might be conducted to assess the espoused goals in a manner comparable across firms. This seven-step process is outlined in Table 1.

The first step in our process is to identify an organizing framework relevant for understanding differences in private family firms' espoused goals. The organizing framework should be grounded in theory and help the researcher make sense of the data produced by the content analysis. For our illustrative study, we draw from organizational identity theory (Albert \& Whetten, 1985) to provide the logic behind our hypotheses as well as to facilitate the identification of the organizing framework for our study. Thus, our framework focuses on examining espoused goals that relate to either the utilitarian or normative organizational identities of family firms (Foreman \& Whetten, 2002; Zachary, McKenny, Short, \& Payne, 2011).

The second step is to identify a sample of private family firms. Research examining firm performance has been critiqued for its sampling practices (Short, Ketchen, $\&$ Palmer, 2002). Thus, researchers should be careful to match the sampling method and the population from which the sample is drawn to the research question (Krippendorff, 2004). Although random sampling is widely 
held as ideal, there are times when other sampling methods may be necessary (Krippendorff, 2004; Neuendorf, 2002). For our demonstration, we use a purposive sampling of the Deakin University list of Australia's top 100 private family businesses as measured by revenue (Glassop, 2009). The Deakin University list is a valuable resource given the difficulty of gathering data on private family businesses in that it identifies a large number of privately held family businesses across multiple industries with sizes ranging from 20 to more than 27,000 employees (Glassop, 2009).

The third step is to select organizational narratives for collection that might contain language reflecting the espoused goals of private family firms. Ideally, the narrative of choice should be one where the producer of the narrative is unaware of the analysis, minimizing contamination of the narrative's content (Krippendorff, 2004). This can be accomplished by relying on texts that can be collected without direct solicitation of the producer, or that were produced in the past (Krippendorff, 2004).

There are a variety of outlets in which private family firms may communicate their salient goals. In our illustration, we look at press releases/posted news articles and "about us" sections of corporate websites. Press releases are used to communicate events and actions associated with the organization (Ashcroft, 2001), conveying to the reader what the organization finds noteworthy. Other studies have also suggested that press releases convey aspects of an organization's identity (Albert \& Whetten, 1985). Press releases are generally targeted at a broad audience external to the company, thus enabling the family business to identify with and relate to the greater business community. Organizational websites also convey the organization's identity through the presentation of information about the purpose and values of the organization (see Lamertz et al., 2005). Indeed, Parmentier (2011) analyzed website content in her study of the development of "family brands," where branding has been argued to be closely tied to the identity of an organization (see Zachary, McKenny, Short, Davis, \& Wu, 2011). Websites are made available to the general public through the Internet; however, it is more likely that prospective or current business partners or others more directly interacting with the organization will access the site than the average member of the company's community. The "about us" website content is particularly salient as this is where the organization most directly answers "Who are we as an organization?" a question that, when answered, identifies aspects of an organizational identity (Dyer \& Whetten, 2006).
The fourth step involves gathering organizational narratives for the selected sample of companies. Of the 100 companies in our sample, we eliminated holding companies and those that no longer had active websites, leaving 93 remaining companies. From this, we included any firm where we could find either the "about us" website text or press releases into our analysis. For each company with an active website, we collected all text from the "about us" section of the website. Of the 93 companies in our sample, we were able to collect the "about us" website text for 77 companies. We also collected the five most recent press releases/posted news articles for each company. If less than five were available, we collected all press releases/posted news articles that were available. Of the 93 companies in our sample, we collected 163 press releases/posted news articles across 40 companies. All data collected ( 77 "about us" website texts and 163 press releases) were coded and used in our analyses.

The fifth step is to examine the sample of organizational narratives, identifying and tabulating any references to goals. In content analysis, a variety of units of data collection are possible (Neuendorf, 2002). For example, researchers may delimit their coding by clause, sentence, paragraph, or overall narrative. Because companies may discuss more than one performance goal within a sentence, we code at the clause level of analysis. As espoused goals are identified, they should be categorized using the organizing framework identified in Step 1. To illustrate this process, the first author read through each document clause by clause and noted each goal identified (see Weber, 1990). In our data, these goals frequently appeared in statements of organizational values, in announcements of awards won, in explicit declaration of the goal, or by reference to examples of the goal being accomplished. However, as with most qualitative analyses, the coder is required to use educated judgment in each case to identify whether a goal is being conveyed. During this process, the coder also classified each goal as either normative or utilitarian based on its alignment with their theoretical definitions and tracked the total number of times each goal was referenced in each narrative (see Short \& Palmer, 2003).

The sixth step is to identify a classification scheme and categorize espoused goals using the scheme. The selection of the classification scheme should be informed by the family business, organizational goals, organizational performance, and other literatures relevant to the study's research question. The purpose of classifying espoused goals is to facilitate the interpretation of the 
Table 2. Normative Goals of Private Family Firms

\begin{tabular}{|c|c|c|c|c|c|}
\hline Goal category & Espoused goals & $\begin{array}{l}\text { “About us" } \\
\text { reference count }\end{array}$ & $\begin{array}{l}\text { Press release } \\
\text { reference count }\end{array}$ & Total reference count & $\%$ Total \\
\hline \multirow[t]{4}{*}{ Quality of work life } & Employee development & 22 & 14 & 36 & \\
\hline & Employee satisfaction & 8 & 5 & 13 & \\
\hline & Work-life balance & 3 & 6 & 9 & \\
\hline & Total & 33 & 25 & 58 & 24.4 \\
\hline \multirow[t]{5}{*}{ Corporate citizenship } & $\begin{array}{l}\text { Donations and community } \\
\text { involvement }\end{array}$ & 14 & 48 & 62 & \\
\hline & Green and sustainability & 21 & 37 & 58 & \\
\hline & Ethical business practices & 14 & 0 & 14 & \\
\hline & Employing the community & 2 & 4 & 6 & \\
\hline & Total & 51 & 89 & 140 & 58.8 \\
\hline \multirow[t]{4}{*}{ Job security } & Employee loyalty & 10 & 7 & 17 & \\
\hline & Family succession & 15 & 4 & 19 & \\
\hline & Employee job security & 3 & I & 4 & \\
\hline & Total & 28 & 12 & 40 & 16.8 \\
\hline Total & & 112 & 126 & 238 & 100 \\
\hline
\end{tabular}

data in the context of the relevant literature, increasing the comparability of the study with other studies looking at performance using the same scheme (Short \& Palmer, 2003). In our example, the first author categorized the espoused goals into two schemes. For utilitarian goals, we used Venkatraman and Ramanujam's (1986) recommendation to distinguish between financial and operational goals. For normative goals, we used the categories of family business goals identified by Tagiuri and Davis (1992), namely, quality of work life, owner's financial security, owner's personal growth, corporate citizenship, and job security. Tagiuri and Davis also identified product development-related goals as being important to family businesses. However, because product-related goals better align with a utilitarian/business identity, these goals were classified as utilitarian. By reviewing the content domain of each classification scheme, the coder was able to assign the most appropriate category to each espoused goal.

In qualitative content analyses, the selection of appropriate classification schemes and parsing of data into these schemes relies significantly on the judgment of the coder. For instance, in this study we classified product development as utilitarian following research in organizational identity. However, other researchers might classify these as normative to remain consistent with frameworks examining categories of goals in family businesses (i.e., Tagiuri \& Davis, 1992). At the end of this step, scholars should be able to assemble tables summarizing the goals that are salient to their sample. In Tables 2 and 3, we present examples of these tables using the goals identified in our sample.

The seventh and final step is to conduct the appropriate statistical analysis for the research question. To investigate the presence of normative and utilitarian goals per our research questions we performed two one-sample $t$ tests with a test value of zero (see Short, Payne, Brigham, Lumpkin, \& Broberg, 2009). The first test addresses whether private family businesses discuss utilitarian goals in their organizational narratives; the second test examines the use of normative goals. Other applications of this method may use other techniques to develop a measurement instrument designed to capture how well private family firms are performing with respect to their espoused goals.

\section{Results}

The research questions guiding this study asked whether private family firms discuss utilitarian and normative goals in their organizational narratives. Our content analysis of private family firm website content and press releases suggests that they do. Research Question 1 asked whether private family firms convey utilitarian goals in organizational narratives. A one-sample $t$ test with a test value of zero found that the private family firms in our 
Table 3. Utilitarian Goals of Private Family Firms

\begin{tabular}{|c|c|c|c|c|c|}
\hline Goal category & Espoused goals & $\begin{array}{c}\text { “About us” } \\
\text { reference count }\end{array}$ & $\begin{array}{l}\text { Press release } \\
\text { reference count }\end{array}$ & $\begin{array}{c}\text { Total reference } \\
\text { count }\end{array}$ & \% Total \\
\hline \multirow[t]{5}{*}{ Financial } & Revenue & 15 & 6 & 21 & \\
\hline & Profit & 1 & 6 & 7 & \\
\hline & Cost control & 3 & 6 & 9 & \\
\hline & Return on investment & 0 & 2 & 2 & \\
\hline & Total & 19 & 20 & 39 & 4.3 \\
\hline \multirow[t]{12}{*}{ Operational } & Number of employees & 27 & 29 & 56 & \\
\hline & Number of locations & 43 & 40 & 83 & \\
\hline & Growth & 50 & 41 & 91 & \\
\hline & Age & 75 & 30 & 105 & \\
\hline & Markets served & 48 & 54 & 102 & \\
\hline & Quantity of product manufactured/sold & 23 & 27 & 50 & \\
\hline & Acquisitions & 4 & 14 & 18 & \\
\hline & Number of customers & 8 & 2 & 10 & \\
\hline & Total land area & 8 & 6 & 14 & \\
\hline & Process excellence & 15 & 10 & 25 & \\
\hline & Productivity & 2 & 9 & II & \\
\hline & Total & 303 & 262 & 565 & 62.2 \\
\hline \multirow[t]{4}{*}{ Product development } & Innovative Initiatives & 54 & 35 & 89 & \\
\hline & Product quality & 58 & 64 & 122 & \\
\hline & Breadth of product offerings & 58 & 36 & 94 & \\
\hline & Total & 170 & 135 & 305 & 33.6 \\
\hline Total & & 492 & 417 & 909 & 100 \\
\hline
\end{tabular}

sample discussed a significant number of utilitarian goals in their "about us" websites $(t=15.67, p<.01)$ and press releases $(t=6.67, p<.01)$. Research Question 2 asked whether private family firms convey normative goals in organizational narratives. Our second onesample $t$ test with a test value of zero found that private family firms in our sample also discussed a significant number of normative goals in their about us websites ( $t=$ $6.78, p<.01)$ and press releases $(t=5.39, p<.01)$.

We found that our sample of private family firms discussed 28 different goals: 10 normative, and 18 utilitarian, as indicated by Tables 2 and 3. The most commonly referenced normative goal category was donations and community involvement. On Twynam Agricultural's website (http://www.twynam.com/), the "about us" page tapped the donations and community involvement goal when highlighting that they focus on "demonstrating commitment to achieving results in partnership with our communities" [italics added]. The most commonly referenced utilitarian goal category was company age, an analog to investigating survival/longevity as a performance indicator. In 2007, Darrell Lea issued a press release celebrating their founding titled "Happy Birthday Darrell Lea! 80 Years Young" [italics added], emphasizing the age of the company. Tables 4 and 5 present examples of how each goal category is manifested in family business narratives.

Interestingly, two normative goal categories thought to be important to family businesses - "owner's financial security" and "personal growth"-were not presented in any of the narratives coded. The relative distribution of espoused goals as shown on Tables 2 and 3 suggest that choice of organizational narrative may influence the probability with which a company will convey certain goals to internal and external constituencies. For instance, the normative goals associated with being involved in the community or making donations to charity were more than three times more common in press releases than in corporate websites. Because press releases are disseminated broadly and to an external audience, they may be more likely to contain espoused goals that affect the entire community or society than a corporate website 
Table 4. Evidence of Normative Family Business Goals

\begin{tabular}{|c|c|c|}
\hline Goal category & Espoused goal & Example \\
\hline \multirow[t]{3}{*}{ Quality of work life } & Employee development & $\begin{array}{l}\text { Primo continually trains and develops young employees for the } \\
\text { challenges that will face them both today and in the future. } \\
\text { (Primo Smallgoods) }\end{array}$ \\
\hline & Employee satisfaction & $\begin{array}{l}\text { The business continues to grow due to its relentless focus on } \\
\text { delivering the best customer service and creating a working } \\
\text { environment that fosters the happiness and development of its } \\
\text { employees. (Peregrine Corporation) }\end{array}$ \\
\hline & Work-life balance & $\begin{array}{l}\text { Therefore, our employee's well-being is paramount; we encourage } \\
\text { personal and professional development, we recognize the } \\
\text { importance of work life balance. (Workpac) }\end{array}$ \\
\hline \multirow[t]{4}{*}{ Corporate citizenship } & $\begin{array}{l}\text { Donations and community } \\
\text { involvement }\end{array}$ & $\begin{array}{l}\text { Community involvement has a high priority within the Tynan } \\
\text { Motor Group, and it has always been a company policy to } \\
\text { encourage staff to join local organisations and community groups. } \\
\text { As such, Tynan Motors sponsors several sporting, cultural and } \\
\text { health organisations throughout the St George and Sutherland } \\
\text { Shire. (Tynan Motors) }\end{array}$ \\
\hline & Green and sustainability & $\begin{array}{l}\text { Fleetcare is mindful of its obligation to contribute to the creation } \\
\text { of a sustainable future for the world by working to build } \\
\text { a sustainable environment and meets the ISO I400 I:2004 } \\
\text { Environmental standards. (Fleetcare) }\end{array}$ \\
\hline & Ethical business practices & $\begin{array}{l}\text { The Altomonte family places a great deal of importance on } \\
\text { honesty, integrity, hard work and loyalty and successfully applies } \\
\text { these standards to their business operations. (Alto Group) }\end{array}$ \\
\hline & Employing the community & $\begin{array}{l}\text { At Midfield, we believe we have a responsibility to the district } \\
\text { which supports us. That's why we play a pivotal role in the } \\
\text { region's day to day life, employing more than } 600 \text { people in a } \\
\text { variety of roles. (Midfield Meat International) }\end{array}$ \\
\hline \multirow[t]{3}{*}{ Job security } & Employee loyalty & $\begin{array}{l}\text { Our staff of loyal long serving employees take great pride } \\
\text { managing these customers and suppliers and the Group is } \\
\text { rewarded with ongoing and continued growth. (Craig Mostyn) }\end{array}$ \\
\hline & Family succession & $\begin{array}{l}\text { To this day, our business is family owned and operated and with } \\
\text { a new generation at the helm we are striving more than ever } \\
\text { to deliver state of the art building and renovation solutions. } \\
\text { (Dahlsens Building Centres) }\end{array}$ \\
\hline & Employee job security & $\begin{array}{l}\text { At the Midfield Group we will continue to grasp and actively } \\
\text { seek out new domestic and export opportunities, to maximise } \\
\text { our success and enhance the secure environment we offer our } \\
\text { employees and their families. (Midfield Meat International) }\end{array}$ \\
\hline
\end{tabular}

that may be viewed by a smaller audience. Similarly, website content may be viewed by prospective employees or business partners to evaluate whether or not to pursue a relationship with the company (Walker et al., 2011; Zachary, McKenny, Short, Davis, et al., 2011). In establishing relationships with companies, establishing trust and an expectation for ethical behavior is frequently an important factor (e.g., Argadoña, 1999). Therefore, it is not surprising that in our sample the goal of engaging in ethical business practices was conveyed through website content rather than press releases. If companies convey different goals depending on the audience of the organizational narrative, those goals pertaining only to the family (internal goals) may be thinly discussed or completely omitted in narratives targeting an external audience such as websites and press releases. This may 
Table 5. Evidence of Utilitarian Family Business Goals

\begin{tabular}{|c|c|c|}
\hline Goal category & Espoused goal & Example \\
\hline \multirow[t]{4}{*}{ Financial } & Revenue & $\begin{array}{l}\text { The Company currently has offices across } 31 \text { cities globally and undertakes } \\
\text { projects worth US\$10 billion annually. (Meinhardt Group) }\end{array}$ \\
\hline & Profit & $\begin{array}{l}\text { We started FY20I0 with clean air and year to date October net profit after } \\
\text { tax was } \$ 1.9 \text { million ahead of budget and } \$ 5.2 \text { million ahead of last year. } \\
\text { (Mitre I0 Australia) }\end{array}$ \\
\hline & Cost control & $\begin{array}{l}\text {... form of efficient cost structures and superior product quality. } \\
\text { (AI Topper) }\end{array}$ \\
\hline & Return on Investment & $\begin{array}{l}\text { We will ensure that we manage our capital resources to enable funding for } \\
\text { growth within each of the group's businesses through investments which are } \\
\text { aligned with our strategy and investment return requirements. (Linfox) }\end{array}$ \\
\hline \multirow[t]{11}{*}{ Operational } & Number of employees & $\begin{array}{l}\text { Costa Logistics is part of the Costa Group of Companies, a company of more } \\
\text { than } 8,000 \text { employees. (Costa's) }\end{array}$ \\
\hline & Number of locations & Today there are I8 APCO EASY SHOP locations. (Apco Service Stations) \\
\hline & Growth & $\begin{array}{l}\text { The Company has achieved rapid and dynamic growth for over three decades. } \\
\text { (Rick Damelian) }\end{array}$ \\
\hline & Age & $\begin{array}{l}\text { We've enjoyed } 30 \text { years of success and collectively look forward to more of } \\
\text { the same over the next } 30 \text { and beyond. (Kailis \& France Foods) }\end{array}$ \\
\hline & Markets served & ... operating in all States in Australia and New Zealand. (Inghams Enterprises) \\
\hline & $\begin{array}{l}\text { Quantity of product } \\
\text { manufactured/sold }\end{array}$ & $\begin{array}{l}\text { In } 2007-2008 \text { Visy: ... Produced more than } 850,000 \text { tonnes of packaging } \\
\text { products. (Visy Industries) }\end{array}$ \\
\hline & Acquisitions & $\begin{array}{l}\text { The FGH board has recognised the need to apply a group-wide perspective } \\
\text { to strategic planning, capital management and investment decisions, including } \\
\text { business acquisitions. (Linfox) }\end{array}$ \\
\hline & Number of customers & $\begin{array}{l}\text { Gough \& Gilmour have been pleased to receive solid support from a large } \\
\text { number of customers. (Gough \& Gilmour) }\end{array}$ \\
\hline & Total land area & $\begin{array}{l}\text { We have adopted a long term view on this corridor acquiring I } 35 \text { hectares of } \\
\text { land several years ago for the purpose of developing a Rail Freight Centre in } \\
\text { that region. (SCT Logistics) }\end{array}$ \\
\hline & Process excellence & $\begin{array}{l}\text { Associated reductions in on-costs and improved Hide handling techniques } \\
\text { enable AIT customers and suppliers to derive mutual benefit in the form of } \\
\text { efficient cost structures. (AI Topper) }\end{array}$ \\
\hline & Productivity & $\begin{array}{l}\text { We conducted an audit of each facility to benchmark financials, staffing and } \\
\text { productivity rates and reviewed the existing IT infrastructure to determine } \\
\text { where improvements were needed. (Costa's) }\end{array}$ \\
\hline \multirow[t]{3}{*}{$\begin{array}{l}\text { Product } \\
\text { development }\end{array}$} & Innovative initiatives & $\begin{array}{l}\text { Leading the fresh produce industry is supported by a high level of innovation } \\
\text { by Moraitis. (Moraitis Group) }\end{array}$ \\
\hline & Product quality & $\begin{array}{l}\text { We have built our foundation on traditional philosophies of excellence } \\
\text { in quality, service and value ... With numbers like that, we know how } \\
\text { important it is to offer excellence across of our business. (Kailis \& France } \\
\text { Foods) }\end{array}$ \\
\hline & Breadth of product offerings & $\begin{array}{l}\text { With over I } 50 \text { innovative designs to choose from, there is a plan to suit every } \\
\text { taste and budget and most size blocks of land. (Coral Homes Group) }\end{array}$ \\
\hline
\end{tabular}

help explain the absence of goal categories "owner's financial security" and "personal growth" in our sample.

We also found that the number of times each goal was discussed in a document varied considerably from goal to goal. Of the utilitarian goals, when growth was discussed in a document it was frequently emphasized by being mentioned multiple times. Specifically, the range of the number of mentions for growth was five in 


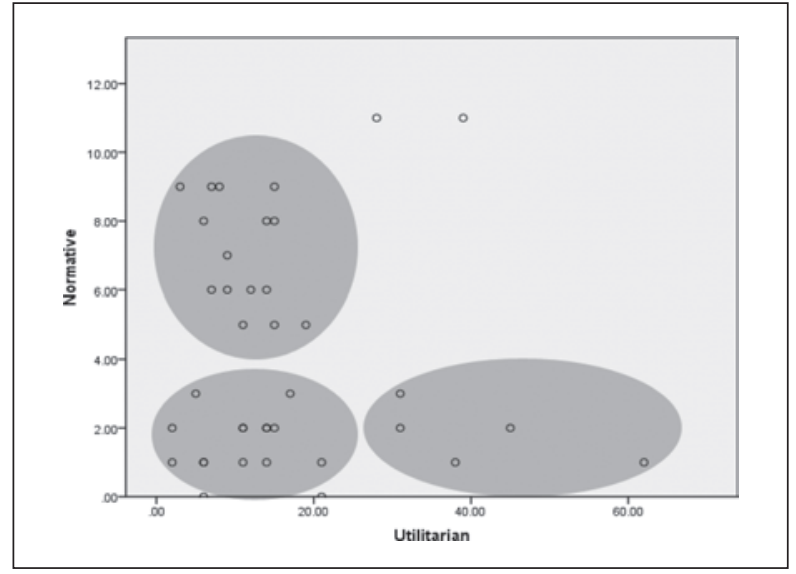

Figure I. Scatter plot of espoused goal portrayal

"about us" website texts and four in press releases (compared with an average range of 2.4 and 2.4, respectively, across all utilitarian goals). Of the normative goals, green and sustainability goals were frequently emphasized in companies' organizational narratives. Specifically, the range of the number of mentions for green and sustainability goals was six in "about us" website texts and five in press releases (compared with an average range of 2.1 and 2.4, respectively, across all normative goals).

To better understand the way in which family firms communicate their normative and utilitarian goals, we provide a scatter plot (Figure 1) illustrating how the firms in our sample with both "about us" website texts and at least one posted press release espouse utilitarian and normative goals. In the scatter plot, we found three regions where private family firms form clusters. The first cluster is low on both espoused normative and utilitarian goals. The second cluster is high on espoused normative goals but lower on utilitarian goals. The last cluster is high on espoused utilitarian goals but lower on normative goals. Interestingly, there are very few firms that are high on both espoused utilitarian and normative goals.

This scatter plot closely aligns with an existing typology of firms classifying family enterprises as "family first" (those with particularly salient normative goals), "business first" (those with particularly salient utilitarian goals), "immature family enterprises" (those low on both utilitarian and normative goals), and "family enterprise first" (those high on both utilitarian and normative goals; Basco \& Pérez Rodriguez, 2009; Ward, 1987).
Our data indicate that a considerable number of private family firms in our sample fall into either "family first," "business first," or "immature family enterprises." Despite being among the top 100 private family firms in Australia, very few appear in the "family enterprise first" quadrant, suggesting that private family firms may have difficulty balancing the business and family identities. Nevertheless, Basco and Pérez Rodriguez (2009) found that "family enterprise first" companies outperformed the other groups on family-related (normative) performance measures and had even or better performance on business-related (utilitarian) performance measures.

Comparing the range of the total count of utilitarian goals espoused by a firm (62) with that of the normative goals (11), it becomes clear that the firms in our sample feel the need to emphasize utilitarian over normative goals. The sampling frame used may help explain why this is the case. The Deakin University list of Australia's top 100 private family businesses is organized in terms of revenue, a utilitarian performance measure (Glassop, 2009). To the extent that firms act in line with their espoused goals, those that espouse utilitarian goals, such as revenue, might be expected to perform better against utilitarian metrics of performance than those espousing primarily normative goals.

To formally assess the validity of the data coded by our process, we correlated total number of financial (utilitarian) goal references and total number of normative goal references on firm revenue, a utilitarian performance metric. We found that the total number of financial goal references was positively correlated with firm revenue $(\rho=.23, p<.05)$; however, the correlation between total number of normative goal references and firm revenue was insignificant $(\rho=.03)$. This suggests that organizations that espouse financial goals such as revenue, profit, and return on investment tend to outperform firms that do not when comparisons are made using a financial measure of performance (e.g., revenue). Thus, our coding of financial (utilitarian) goals shows evidence of predictive validity. These results also suggest that revenue is likely not a suitable measure of normative performance that provides preliminary evidence of discriminant validity.

In our coding, we also made note of content that might differentiate these Australian firms from firms outside the country. We found comments such as: "By Australasia, for Australasia," "Hazell Bros is proudly Tasmanian," 
and "Wholly Australian owned" throughout the coding process. These comments indicate that within-nation/ region ownership is a salient aspect of the organizational identity of the private family firms in our sample.

\section{DICTION Post Hoc Analysis}

Another content analytic technique, computer-aided content analysis, can help researchers examine the performance characteristics of private family firms through the analysis of organizational narratives. As a post hoc analysis, we highlight the use of one particular software package-DICTION. The name DICTION refers to the predefined and custom word dictionaries that drive the functionality of the program. Although a number of software packages offer predefined dictionaries, DICTION has been noted for its potential to provide insightful information of interest to researchers in strategic management (Short \& Palmer, 2008). Given the importance of understanding the organizational performance of family firms to the family business literature (Chua et al., 1999), we illustrate how DICTION can be used to provide a number of variables of interest to family business scholars seeking to better understand how organizational narratives may shed light on the performance of private family firms.

DICTION has proven to be a valuable tool for facilitating content analysis in strategic management (Short \& Palmer, 2008), leadership (Bligh, Kohles, \& Meindl, 2004), and accounting (Rogers, Dillard, \& Yuthas, 2005). However, DICTION was originally developed to facilitate the analysis of political texts (Hart, 2000, 2001). The development of DICTION was theoretically grounded in linguistic theory (Bligh et al., 2004) and was inspired by work both in the political sciences domain (e.g., Barber, 1992) and in the greater social sciences (e.g., Osgood, Suci, \& Tannenbaum, 1957). For instance, the measurement of optimism in DICTION was inspired by the book that discussed the pivotal role of optimism in the shaping of a U.S. president's character, which is thought to influence the performance in the White House (Barber, 1992). This idea of optimism influencing performance extends beyond the political science literature, however. In the management literature, recent work has indicated a relationship between optimism and business performance as well (Hmieleski \& Baron, 2009).

DICTION begins by measuring a number of "master" variables that examine specific qualities of the language in narrative texts (Hart, 2000). Specifically, DICTION measures certainty, optimism, activity, realism, and communality. Certainty involves language that indicates resoluteness, inflexibility, completeness, and a tendency to speak with authority. Optimism involves language endorsing some person, group, concept, or event. Activity examines language featuring movement, change, and implementation of ideas and the avoidance of inertia. Realism examines language describing tangible, immediate, recognizable matters. Finally, commonality is an approximation of the communitarian concepts found in the work of Etzioni (1993) that examines language that highlights shared group values.

DICTION also creates a number of "calculated" variables that are based on lexical patterns found in the text. These variables include insistence (the use of repeated words), variety (the number of different words in a passage divided by the passage's total words), embellishment (the ratio of adjectives to verbs), and complexity (the average number of characters per word in a text).

To illustrate the potential uses of DICTION, we analyze the output for two firms' narratives. Bettis (1991) suggested that much can be learned by looking at outliers. As such, we selected two firms from our sample that had documents that deviated from the average DICTION scores on various dimensions. Specifically, we had DICTION process the "about us" website content from Visy Industries and a press release from Linfox. We then compared the values for each variable with those of the rest of our sample using one-sample $t$ tests. Table 6 presents the results from this analysis.

Our analyses show that Visy Industries' "about us" website text is significantly different from the rest of the sample along multiple dimensions. Having relatively high optimism and activity scores might suggest that Visy Industries feels that they are actively pursuing their espoused goals and are generally positive regarding the company's ability to perform against them. Optimism has also been associated with improved performance at the individual level (Brown \& Marshall, 2001), suggesting that higher levels of optimism conveyed by Visy Industries may also be an indicator for a high level of performance against their goals. The low certainty score, however, could indicate flexibility or tentativeness that might suggest insecurity about whether the espoused goals are the right ones to pursue.

Linfox's press release is significantly different along all of the "master" and "calculated" variables provided 
Table 6. Evidence of Performance Rhetoric on Family Business Narratives

\begin{tabular}{|c|c|c|c|c|}
\hline \multirow[b]{2}{*}{ DICTION variable } & \multicolumn{4}{|c|}{ One-sample $t$ test } \\
\hline & Visy Industries website & Average (websites) & Linfox press release & Average (press releases) \\
\hline \multicolumn{5}{|l|}{ Calculated variables } \\
\hline Insistence & 119.40 & 140.83 & 467.80** & 35.67 \\
\hline Embellishment & $0.59 * *$ & 1.00 & $0.6 I^{* *}$ & 1.34 \\
\hline Variety & $0.59 * *$ & 0.62 & $0.44 * *$ & 0.59 \\
\hline Complexity & 5.48 & 5.41 & $5.19 * *$ & 5.00 \\
\hline \multicolumn{5}{|l|}{ Master variables } \\
\hline Activity & $52.89 * *$ & 49.32 & $46.57 * *$ & 49.34 \\
\hline Optimism & $55.67 * *$ & 53.37 & $50.50 * *$ & 53.06 \\
\hline Certainty & 43.2I** & 49.49 & $62.55 * *$ & 46.57 \\
\hline Realism & $44.36 * *$ & 45.52 & $44.53^{* *}$ & 45.69 \\
\hline Commonality & 49.47 & 48.78 & $49.74 * *$ & 8.63 \\
\hline
\end{tabular}

Note. Bolded values reflect variables discussed in the text. $* * p<.0$ I.

Table 7. Correlations Between Utilitarian/Normative Goals and DICTIONVariables

\begin{tabular}{|c|c|c|c|c|c|c|c|c|c|c|c|}
\hline & I & 2 & 3 & 4 & 5 & 6 & 7 & 8 & 9 & 10 & II \\
\hline I. Utilitarian & 1.00 & & & & & & & & & & \\
\hline 2. Normative & .11 & 1.00 & & & & & & & & & \\
\hline 3. Insistence & $.38^{* *}$ & .11 & 1.00 & & & & & & & & \\
\hline 4. Embellishment & -.02 & $.23 *$ & -.09 & 1.00 & & & & & & & \\
\hline 5. Variety & $-.58 * *$ & $.27^{*}$ & $-.69 * *$ & .06 & 1.00 & & & & & & \\
\hline 6. Complexity & -.07 & -.10 & .10 & -.08 & .20 & 1.00 & & & & & \\
\hline 7. Activity & .03 & -.15 & -.08 & $-.73^{* *}$ & .03 & .16 & 1.00 & & & & \\
\hline 8. Optimism & -.05 & $.23 *$ & -.13 & .26 & .13 & -.01 & -.13 & 1.00 & & & \\
\hline 9. Certainty & $.38 * *$ & .17 & $.62 * *$ & -.03 & $-.67 * *$ & -.05 & -.17 & -.14 & 1.00 & & \\
\hline 10. Realism & .09 & .04 & -.03 & -.21 & -.15 & $-.66 * *$ & .12 & .01 & -.01 & 1.00 & \\
\hline II. Commonality & .11 & .19 & .13 & -.04 & -.18 & -.10 & .06 & $.40 * *$ & .05 & .15 & 1.00 \\
\hline
\end{tabular}

Note. Bolded values reflect variables discussed in the text. $* p<.05 . * * p<.01$.

by DICTION. The extremely high insistence and relatively high certainty scores might indicate that the goals presented in the press release are very important to Linfox and thus are worthy of repetition. The degree of certainty that a top management team has about its environment and strategy has also been shown to positively influence organizational performance (Isabella \& Waddock, 1994). Additionally, studies of social entrepreneurship have looked at high commonality scores as being reflective of a normative identity, communicating the firm's embeddedness within a larger community (Moss et al., 2011). By extension, Linfox might have a greater emphasis on normative goals than a firm with a lower commonality score.

To assess the extent to which the standard variables provided by DICTION can inform family firm scholars about the espoused normative and utilitarian goals of private family firms, we created a correlation matrix showing the relationships between the DICTION variables and variables indicating the frequency with which firms discussed normative or utilitarian goals on the companies' websites. Table 7 presents this matrix.

The variable denoting the number of times utilitarian goals were discussed was positively associated with 
insistence $(\rho=.38, p<.01)$ and certainty $(\rho=.38, p<.01)$ but negatively related to variety $(\rho=-.58, p<.01)$. The positive relationship with insistence and certainty might suggest that the language used by companies espousing utilitarian goals tends to emphasize and reiterate points while downplaying uncertainty or risk. Specifically, the firms espousing utilitarian goals might communicate using transactional and to-the-point language. Firms espousing normative goals appear to communicate differently. The variable denoting the number of times normative goals were discussed was positively associated with embellishment $(\rho=.23, p<.05)$ and optimism $(\rho=.23$, $p<.05)$ but negatively correlated with variety $(\rho=-.27$, $p<.05)$. The positive relationships with optimism and embellishment might suggest more colorful and personable language. Both variables accounting for firms espousing utilitarian and normative goals have a negative relationship with variety, which might suggest that firms that do communicate their goals via these organizational narratives do not use an abundance of different words in an effort to keep the message clear to the intended audience.

\section{Discussion}

This article illustrates how content analysis can be used to assess the espoused goals of private family firms. In doing so, we make two key contributions to the family business literature. First, we outline and demonstrate the use of the first content analytic method to gather, examine, and assess the espoused normative and utilitarian goals of private family firms. Because of the importance of private family businesses (Westhead \& Howorth, 2006) and a general trend toward the use of more sophisticated empirical techniques in family business research (Sharma, 2010), it is imperative that family business researchers continue to expand their methodological capabilities. Second, we demonstrate how computer-aided content analysis tools, such as DICTION, can be applied to study the use of language in private family firms' organizational narratives. Taken together, the manual coding process and computer-aided content analyses can help researchers better understand the salient espoused goals of private family businesses.

Similar to others advocating a balanced scorecard approach that examines financial, customer, internal business, and innovation/learning-based goals in family businesses (Craig \& Moores, 2005), we argue for the importance of incorporating diverse goals into understanding the overall performance of family businesses. Following strategic reference point theory, which states that businesses use internal, external, and/or time-related referents to gauge performance (Fiegenbaum, Hart, \& Schendel, 1996), we argue that such referents can be identified using content analysis of narratives and that these may be reasonable indicators of objective performance (Short \& Palmer, 2003). Below we more extensively discuss the method demonstrated in this article and identify several areas where future research can use this method to further our understanding of privately held family businesses.

Despite the several contributions of this study, some consideration should be given to its limitations. We used a sample of Australian firms to illustrate the use of our content analytic process. It is possible that the salient espoused goals found in our illustrative analysis would differ in a sample of private family firms from another country, or even with the same sample 10 years from now. It is also possible that the narratives used by family firms in Australia to communicate with stakeholders differ from those in other countries. Nevertheless, the process by which the salient espoused goals are measured could be applied to a variety of organizational narratives and of firms from a variety of countries. This study assessed the espoused goals of a sample of private family firms as an illustrative example of the content analytic process. Future researchers using this method can build on our efforts by examining the content, external, discriminant, and predictive validity as well as reliability considerations documented in the content analysis literature in conducting their studies (e.g., Neuendorf, 2002; Short, Broberg, Cogliser, \& Brigham, 2010; Weber, 1990). Finally, our illustrative example did not attempt to explain theoretically why some goals were more salient than others in our sample of private family firms, thus limiting the generalizability of our findings to other samples. Future studies might do so to enable theoretical generalization to the population of private family firms or family firms in general.

Content analysis is a flexible methodology that can be used to identify what the espoused goals of family businesses are and to assess which utilitarian and normative goals are most salient to a particular group of family businesses. In other words, various organizational characteristics of family firms (e.g., age, leadership, ownership, size, strategy, structure) can be examined in relation to the identified goals to better understand how various types of firms approach performance. These characteristics can be analyzed independently and/or collectively, perhaps using an 
organizational configurations perspective. Organizational configurations are groupings of similar firms that can be identified by common organizational features (Short, Payne, \& Ketchen, 2008). The organizational configurations perspective has been used in the organizational image/identity literature to understand how companies in the Canadian brewing industry create positive organizational images in a variety of external environments (Lamertz et al., 2005). To integrate the configurations literature into family business research, a potential study could create strategic groupings of family firms (e.g., Short, Ketchen, Palmer, \& Hult, 2007).

Organizational identity might also continue to shed light on the family business goals literature by extending our illustrative example to a sample of both family and nonfamily firms. This study could then identify the extent to which family business goals overlap nonfamily business goals. Both family and nonfamily firms share the utilitarian (business) identity (Foreman \& Whetten, 2002; Zachary, McKenny, Short, \& Payne, 2011), suggesting that there will be considerable overlap in the espoused utilitarian goals. Although the normative (family) identity is not shared by nonfamily firms, a recent study indicated that some firms have social (normative) identities (Moss et al., 2011). To the extent that attentiveness to corporate social responsibility continues to spread in the business community, the espoused goals shared by the family and social normative identities (e.g., donations and community involvement, ethical business practices) may also overlap. However, those espoused goals drawing directly on the values of the family (e.g., family succession, extracting benefits for the family) would likely remain more prevalent in family firms (Sorenson et al., 2009).

Future research may also benefit by exploring the differences between private family firms and publicly traded family businesses in their emphasis on utilitarian and normative goals in various documents. A study examining potential differences might compare the various organizational narratives, including shareholder letters (Short et al., 2009), websites (Jose \& Lee, 2007; Lamertz et al., 2005; Micelotta \& Raynard, 2011), press releases (Froehlich \& Rüdiger, 2006; Henry, 2006), mission statements (O'Gorman \& Doran, 1999; Pearce \& David, 1987), e-mail correspondence (Jun \& Cai, 2001), and executive meeting transcripts (Tuggle, Schnatterly, \& Johnson, 2010), to examine not only differences between the espoused goals of family and nonfamily businesses but also the extent to which the companies are consistent across media in their emphasis on certain goals. Short and Palmer (2003) highlight that public documents such as shareholder letters may contain self-serving rhetoric; however, by triangulating the rhetoric among various data sources, public and private, researchers might identify the extent to which this affects identity-related rhetoric.

Goals research, both inside and outside the family business literature, has indicated that when an organization adopts multiple goals, the goals may become incompatible(Perrow, 1968; Tagiuri \& Davis, 1992). Furthermore, the clusters identified in Figure 1 indicate that few private family businesses in our sample emphasized both normative and utilitarian goals to a great degree. Nevertheless, other studies show family businesses pursuing a variety of goals and being successful in performing well against both family- and business-related goals (e.g., Basco \& Pérez Rodriguez, 2009). To make sense of these findings, a future study could look at combinations of espoused goals or goal categories to identify theoretically what aspects of goals lead to their conflict with or compatibility with other goals. Furthermore, this study could identify the factors influencing the successful management of these diverse goals.

The methods presented here can be extended to research questions beyond the measurement of espoused goals. Content analysis has also been used to investigate other phenomena of interest to the family business literature (e.g., Micelotta \& Raynard, 2011; Parmentier, 2011; Short et al., 2009) and could be leveraged to assess other difficult-to-measure aspects of private family firms. For example, when analyzing the documents used in this study, we found that performance against some of the espoused goals was explicitly quantified in the narrative. For example, in their posted news article regarding the implementation of a workplace safety program, Border Express (2010) stated, "A self-insurance division was created ... for the 750 employees [italics added] nationally," thus providing quantified data on the size of the organization. Data presented in this fashion could be incorporated directly into quantitative analyses, in this case using the change in number of employees over time as a measure of firm growth. Furthermore, if firms consistently reported such data over time, degrees of change in various measures might be gleaned. That said, such disclosures must be closely examined for accuracy and relevance, particularly across various constructs, data sources, and time frames. Indeed, future studies might examine multiple organizational narratives to 
Table 8. Additional Sources of Private Family Business Goals

\begin{tabular}{lll}
\hline Goal category & \multicolumn{1}{c}{ Data source } & \multicolumn{1}{c}{ Potential goal } \\
\hline Quality of work life & Recruitment materials & Employee development \\
Owner's financial security & E-mail correspondence & Founding family quality of life \\
Product development & Advertisements & Innovative initiatives \\
Personal growth & Founder speech/presentation transcripts & Autonomy in decision making \\
Corporate citizenship & Nonprofit donation records & Donations and community involvement \\
Job security & HR training materials & Employee job security \\
Financial & Press packets & Revenue \\
Operational & Mission statements & Growth \\
\hline
\end{tabular}

determine to what extent organizations tell consistent stories and to compare with objective data, if such data are available.

Table 8 identifies other narratives that might be useful to family business researchers as well as potential goals that might be measured using these narratives. The content analytic process outlined in this article along with these alternative data sources opens a door for future research into the goals of private family businesses. We found that two of the family business goal categories identified by Tagiuri and Davis (1992) were not conveyed in our sample. Specifically, neither the owner's personal growth nor financial security goals were presented in the "about us" website content or press releases. This highlights that different narratives might be more or less likely to contain references to certain goal categories. For example, goals relating to benefits accruing only to the family are likely to be more prevalent in communications with the family. A future study might content analyze intrafamily e-mail or memoranda to determine the extent to which the audience of a narrative influences the types of goals presented.

Another application of content analysis with other organizational narratives might help resolve a challenge that may be faced by family businesses related to the distinction between family and nonfamily employees (Astrachan \& McMillan, 2003). This creates an interesting question for understanding the human resources practices of family businesses: How does employee recruitment and development differ between family and nonfamily businesses (Astrachan \& Kolenko, 1994; Lansberg, 1983)? One future study might look at recruitment materials to measure employee recruitment and development-related goals (see Eldson \& Iyer, 1999; Walker et al., 2011). Specifically, the study could compare family businesses' emphasis on employee development with nonfamily firms and identify whether family and nonfamily businesses differ in their areas of focus within their overarching development goals. Another study might investigate the extent to which various espoused goals differ or are shared across each of these different narratives. The findings of such a study would facilitate the appropriate selection of organizational narratives to detect whether specific goals are espoused in a sample of private family firms.

The correlations among the master and calculated DICTION variables, although sample specific, may also suggest future studies looking at the language with which family businesses communicate with their stakeholders. For example, the commonality variable was positively related to optimism $(\rho=.40, p<.01)$. Since families are thought to exhibit socially responsible behaviors in part to shape the family's image and reputation in the community (Dyer \& Whetten, 2006), a future study could look at how family businesses use optimistic rhetoric in conjunction with community-related goals to shape the community's image of the organization. Another interesting correlation is the strong negative correlation between activity and embellishment $(\rho=-.73, p<.01)$. Since activity looks at change and overcoming inertia, a negative relationship with embellishment might suggest that family businesses that are stagnant, or beginning to stagnate, may use colorful, rich language on their websites to draw the reader's attention away from this point. Future studies might then look at how family firms use of organizational impression management techniques (see Bolino, Kacmar, Turnley \& Gilstrap, 2008) in communications with external stakeholders, and whether this differs significantly from nonfamily firms.

Many operationalizations of "family business" have been used; however, a universally accepted method for delineating between family and nonfamily businesses 
remains to be established (Chrisman, Chua, \& Sharma, 2005). For instance, we operationalized family business status by examining the percentage of family ownership and through self-identification (see Gulbrandsen, 2005; Naldi, Nordqvist, Sjöberg, \& Wiklund, 2007). Other studies, however, have identified a family business by the presence of family members in top management (e.g., Dyer \& Whetten, 2006) and the behavior of the organization (e.g., Chua et al., 1999). Because these different operationalizations tap on different aspects of being a family firm (e.g., ownership, management, transgenerational succession), each method of identifying family firms is likely to identify a different set of family businesses. In an effort to identify which of these operationalizations have the best predictive validity, a future study might identify a sample of firms as family/nonfamily using each of these operationalizations and compare the emphasis in decidedly family-related goals (e.g., founding family quality of life, employment of family members) among classifications. Such a study could draw from a number of external and internal narratives, such as e-mail correspondence, websites, meeting transcripts, and mission statements. The study would also present the opportunity to use content analysis to measure non-goal-related constructs such as "familiness." Familiness represents the resources and capabilities associated with the involvement and interactions of family members (Chrisman, Chua, \& Litz, 2003). The proposed study could identify which operationalization of family business tends to have the highest level of familiness.

Much of our study has centered on the methodological importance of assessing the normative and utilitarian goals of private family businesses; however, this study may also inform practice. The literature looking at acquisitions of family businesses underscores the practical importance of understanding the value of goals in family businesses. A recent study found that acquirers of family businesses typically pay less for the company than they would for a similarly performing nonfamily firm (Granata \& Chirico, 2010). However, given that family businesses typically pursue multiple family- and business-related goals, some resources that could be used toward business-related goals are likely deployed toward pursuing family-related goals before the acquisition. When the new professional management team replaces the old family management, these resources could be redeployed in pursuit of business-related goals, netting an increase in resources deployed pursuing business-related goals, compared with firms that were not family firms before the acquisition. This outcome is supported by two studies finding that acquisitions of family businesses tend to outperform those of similar nonfamily businesses in terms of the acquirer's shareholder value creation (Block, 2010; Feito-Ruiz \& Menéndez-Requejo, 2010). Thus, understanding both the utilitarian and normative goals of private family businesses carries practical as well as methodological implications.

\section{Conclusion}

According to Chua et al. (1999), "understanding, predicting, and modifying behavior to help family business achieve their goals and improve their performance are the object of family business management research" (p. 35). To date, progress toward this objective has been hampered by limitations in available data from privately held family firms, particularly data associated with organizational performance. This study facilitates research in this area by demonstrating how narrative analyses can be used to identify the salient espoused goals of private family firms.

\section{Declaration of Conflicting Interests}

The author(s) declared no potential conflicts of interests with respect to the research, authorship, and/or publication of this article.

\section{Funding}

The author(s) received no financial support for the research, authorship, and/or publication of this article.

\section{References}

Albert, S., \& Whetten, D. (1985). Organizational identity. In B. M. Staw \& L. L. Cummings (Eds.), Research in organizational behavior (Vol. 7, pp. 263-295). Greenwich, CT: JAI Press.

Argadoña, A. (1999). Sharing out in alliances: Trust and ethics. Journal of Business Ethics, 21, 217-228.

Ashcroft, L. (2001). PR, marketing and the Internet: Implications for information professionals. Library Management, $22(1 / 2), 68-74$.

Ashforth, B. E., \& Mael, F. (1989). Social identity theory and the organization. Academy of Management Review, 14(1), 20-39. 
Astrachan, J. H., \& Kolenko, T. A. (1994). A neglected factor in explaining family business success: Human resources practices. Family Business Review, 7, 251-262.

Astrachan, J. H., \& McMillan, K. S. (2003). Conflict and communication in the family business. Marietta, GA: Family Enterprise.

Barber, J. D. (1992). The presidential character: Predicting performance in the White House (4th ed.). Englewood Cliffs, NJ: Prentice Hall.

Barney, J. B., Bundeson, J. S., Foreman, P. O., Gustafson, L. T., Huff, A. S., Martins, L. L., . . Stimpert, L. (1998). A strategy conversation on the topic of organizational identity. In D. A. Whetten \& P. C. Godfrey (Eds.), Identity in organizations: Building theory through conversations (pp. 99-168). Thousand Oaks, CA: SAGE.

Basco, R., \& Pérez Rodriguez, M. J. (2009). Studying the family enterprise holistically: Evidence for integrated family and business systems. Family Business Review, 22, 82-95.

Bettis, R. (1991). Strategic management and the straightjacket: An editorial essay. Organization Science, 2, 315-319.

Bligh, M. C., Kohles, J. C., \& Meindl, J. R. (2004). Charting the language of leadership: A methodological investigation of President Bush and the crisis of 9/11. Journal of Applied Psychology, 89, 562-574.

Block, J. (2010). Family management, family ownership, and downsizing: Evidence from S\&P 500 firms. Family Business Review, 23, 109-130.

Bolino, M. C., Kacmar, K. M., Turnley, W. H., \& Gilstrap, J. B. (2008). A multi-level review of impression management motives and behaviors. Journal of Management, 34, 1080-1109.

Border Express. (2010). Express a safety finalist [Press release]. Retrieved from http://www.borderexpress.com.au/downloads/MWE-06-2010-08-04.pdf

Brown, J. D., \& Marshall, M. A. (2001). Great expectations: Optimism and pessimism in achievement settings. In E. C. Chang (Ed.), Optimism \& pessimism: Implications for theory, research, and practice (pp. 239-255). Washington, DC: American Psychological Association.

Carlock, R. S., \& Ward, J. L. (2001). Strategic planning for the family business. New York, NY: Palgrave Macmillan.

Carney, M. (2005). Corporate governance and competitive advantage in family-controlled firms. Entrepreneurship Theory and Practice, 29, 249-265.

Chrisman, J. J., Chua, J. H., \& Litz, R. (2003). A unified systems perspective of family firm performance: An extension and integration. Journal of Business Venturing, 18 , 467-472.
Chrisman, J. J., Chua, J. H., \& Sharma, P. (1998). Important attributes of successors in family businesses: An exploratory study. Family Business Review, 11, 19-34.

Chrisman, J. J., Chua, J. H., \& Sharma, P. (2005). Trends and directions in the development of a strategic management theory of the family firm. Entrepreneurship Theory and Practice, 29, 555-576.

Chrisman, J. J., Kellermanns, F. W., Chan, K. C., \& Liano, K. (2010). Intellectual foundations of current research in family business: An identification and review of 25 influential articles. Family Business Review, 23, 9-26.

Chua, J. H., Chrisman, J. J., \& Sharma, P. (1999). Defining the family business by behavior. Entrepreneurship Theory and Practice, 23(4), 19-39.

Chua, J. H., Chrisman, J. J., \& Sharma, P. (2003). Succession and non-succession concerns of family firms and agency relationships with nonfamily managers. Family Business Review, 16, 89-107.

Craig, J., \& Moores, K. (2005). Balanced scorecards to drive the strategic planning of family firms. Family Business Review, 18, 105-122.

Crane, A. (2000). Corporate greening as amoralization. Organization Studies, 21, 673-696.

DarrellLea.(2007).HappybirthdayDarrellLea![Press release]. Retrieved from http://www.darrelllea.com/pdf/80th\% 20Birthday\%20Release.pdf

Dess, G. G., \& Robinson, R. B., Jr. (1984). Measuring organizational performance in the absence of objective measures: The case of the privately-held firm and conglomerate business unit. Strategic Management Journal, 5, 265-273.

Dutton, J. E., \& Dukerich, J. M. (1991). Keeping an eye on the mirror: Image and identity in organizational adaptation. Academy of Management Journal, 34, 517-554.

Dyer, W. G., Jr., \& Whetten, D. A. (2006). Family firms and social responsibility: Preliminary evidence from the S\&P 500. Entrepreneurship Theory and Practice, 30, 785-802.

Eldson, R., \& Iyer, S. (1999). Creating value and retention through employee development: The Sun Microsystems experience. Human Resource Planning, 22(2), 39-47.

Etzioni, A. (1993). The spirit of community: Rights, responsibilities, and the communitarian agenda. New York, NY: Crown.

Feito-Ruiz, I., \& Menéndez-Requejo, S. (2010). Family firm mergers and acquisitions in different legal environments. Family Business Review, 23, 60-75.

Fiegenbaum, A., Hart, S., \& Schendel, D. (1996). Strategic reference point theory. Strategic Management Journal, 17, 219-235. 
Foreman,P.,\&Whetten,D.A.(2002).Members'identificationwith multiple-identity organizations. Organization Science, 13, 618-635.

Freeman, E. (1984). Strategic management: A stakeholder approach. Boston, MA: Pitman.

Froehlich, R., \& Rüdiger, B. (2006). Framing political public relations: Measuring success of political communication strategies in Germany. Public Relations Review, 32(1), $18-25$.

Glassop, L. (2009). Australia's top 100 private family firms. Melbourne, Victoria, Australia: Deakin University.

Gómez-Mejía, L. R., Haynes, K. T., Núñez-Nickel, M., Jacobson, K. J. L., \& Moyano-Fuentes, J. (2007). Socioemotional wealth and business risks in family-controlled firms: Evidence from Spanish olive oil mills. Administrative Science Quarterly, 52, 106-137.

Gómez-Mejía, L. R., Makri, M., \& Larraza Kintana, M. (2010). Diversification decisions in family-controlled firms. Journal of Management Studies, 47, 223-252.

Granata, D., \& Chirico, F. (2010). Measures of value in acquisitions: Family versus nonfamily firms. Family Business Review, 23, 341-354.

Gulbrandsen, T. (2005). Flexibility in Norwegian familyowned enterprises. Family Business Review, 18, 57-76.

Hart, R. P. (2000). DICTION 5.0: The text-analysis program. Thousand Oaks, CA: SAGE.

Hart, R. P. (2001). Redeveloping DICTION: Theoretical considerations. In M. D. West (Ed.), Theory, method, and practice in computer content analysis (pp. 43-60). New York, NY: Springer.

Henry, E. (2006). Market reaction to verbal components of earnings press releases: Event study using a predictive algorithm. Journal of Emerging Technologies in Accounting, 3, $1-19$.

Hmieleski, K. M., \& Baron, R. A. (2009). Entrepreneurs' optimism and new venture performance: A social cognitive perspective. Academy of Management Journal, 52, 473-488.

Isabella, L. A., \& Waddock, S. A. (1994). Top management team certainty: Environmental assessments, teamwork, and performance implications. Journal of Management, $20,835-858$.

Jose, A., \& Lee, S.-M. (2007). Environmental reporting of global corporations: A content analysis based on website disclosures. Journal of Business Ethics, 72, 307-321.

Jun, M., \& Cai, S. (2001). The key determinants of Internet banking service quality: A content analysis. International Journal of Bank Marketing, 19, 276-291.
Krippendorff, K. (2004). Content analysis: An introduction to its methodology. Thousand Oaks, CA: SAGE.

Lamertz, K., Heugens, P. P. M. A. R., \& Calmet, L. (2005). The configuration of organizational images among firms in the Canadian beer brewing industry. Journal of Management Studies, 42, 817-843.

Lansberg, I. S. (1983). Managing human resources in family firms: The problem of institutional overlap. Organizational Dynamics, 12, 39-46.

Lee, J. (2006). Family firm performance: Further evidence. Family Business Review, 19, 103-114.

Lubatkin, M. H, Ling, Y., \& Schulze, W. S. (2003, August). Explaining agency problems in family firms using behavioral economics and justice theories. Paper presented at the annual meeting of the Academy of Management, Seattle, WA.

McConaughy, D. L., \& Phillips, G. M. (1999). Founders versus descendants: The profitability, efficiency, growth characteristics and financing in large, public, founding-familycontrolled firms. Family Business Review, 12, 123-131.

Micelotta, E. R., \& Raynard, M. (2011). Concealing or revealing the family? Corporate brand identity strategies in family firms. Family Business Review. Advance online publication. doi: $10.1177 / 0894486511407321$

Morris, M. H., Williams, R. O., Allen, J. A., \& Avila, R. A. (1997). Correlates of success in family business transitions. Journal of Business Venturing, 12, 385-401.

Moss, T. W., Short, J. C., Payne, G. T., \& Lumpkin, G. T. (2011). Dual identities in social ventures: An exploratory study. Entrepreneurship Theory and Practice, 35, 805-830. doi:10.1111/j.1540-6520.2010.00372.x

Murphy, D. (2005). Understanding the complexities of private family firms: An empirical examination. Family Business Review, 18, 123-133.

Naldi, L., Nordqvist, M., Sjöberg, K., \& Wiklund, J. (2007). Entrepreneurial orientation, risk taking, and performance in family businesses. Family Business Review, 20, $33-47$.

Neuendorf, K. A. (2002). The content analysis guidebook. Thousand Oaks, CA: SAGE.

O'Gorman, C., \& Doran, R. (1999). Mission statements in small and medium-sized businesses. Journal of Small Business Management, 37(4), 59-66.

Olson,P.D.,Zuiker, V.S.,Danes, S.M.,Stafford,K.,Heck,R.K.Z., \& Duncan, K. A. (2003). The impact of the family and the business on family business sustainability. Journal of Business Venturing, 18, 639-666. 
Osgood, C. E., Suci, G. J., \& Tannenbaum, P. (1957). The measurement of meaning. Urbana-Champaign: University of Illinois Press.

Palmer, T. B., \& Short, J. C. (2008). Mission statements in U.S. colleges of business: An empirical examination of their content with linkages to configurations and performance. Academy of Management Learning and Education, 7, 454-470.

Parmentier, M.-A. (2011). When David met Victoria: Forging a strong family brand. Family Business Review, 23, 217-232. doi:10.1177/0894486511408415

Pearce, J. A., \& David, F. (1987). Corporate mission statements: The bottom line. Academy of Management Executive, 1, 109-116.

Perrow, C. (1961). The analysis of goals in complex organizations. American Sociological Review, 26, 854-866.

Perrow, C. (1968). Organizational goals. In D. L. Sills \& R. K. Merton (Eds). International encyclopedia of the social sciences (pp. 305-361), New York, NY: Macmillan.

Richard, P. J., Devinney, G. S., Yip, G. S., \& Johnson, G. (2009). Measuring organizational performance: Towards methodological best practice. Journal of Management, 35, 718-804.

Rogers, R. K., Dillard, J., \& Yuthas, K. (2005). The accounting profession: Substantive change and/or image management. Journal of Business Ethics, 58(1-3), 159-176.

Roth, K., \& Ricks, D. A. (1994). Goal configuration in a global industry context. Strategic Management Journal, 15, $103-120$

Salvato, C., \& Moores, K. (2010). Research on accounting in family firms: Past accomplishments and future challenges. Family Business Review, 23, 193-215.

Sharma, P. (2004). An overview of the field of family business studies: Current status and directions for the future. Family Business Review, 17, 1-36.

Sharma, P. (2010). Editor's note: 2009-A year in Review [Editorial]. Family Business Review, 23, 5-8.

Sharma, P., Chrisman, J. J., \& Chua, J. H. (1997). Strategic management of the family business: Past research and future challenges. Family Business Review, 10, 1-36.

Sharma, P., Chrisman, J. J., Pablo, A. L., \& Chua, J. H. (2001). Determinants of initial satisfaction with the succession process in family firms: A conceptual model. Entrepreneurship Theory and Practice, 25(3), 17-35.

Short, J. C., Broberg, J. C., Cogliser, C. C., \& Brigham, K. H. (2010). Construct validation using computer-aided text analysis (CATA): An illustration using entrepreneurial orientation. Organizational Research Methods, 13, 320-347.
Short, J. C., Ketchen, D. J., \& Palmer, T. B. (2002). The role of sampling in strategic management research on performance: A two-study analysis. Journal of Management, 28, 363-385.

Short, J. C., Ketchen, D. J., Palmer, T. B., \& Hult, G. T. M. (2007). Firm, strategic group, and industry influences on performance. Strategic Management Journal, 28, 147-167.

Short, J. C., \& Palmer, T. B. (2003). Organizational performance referents: An empirical examination of their content and influences. Organizational Behavior and Human Decision Processes, 90, 209-224.

Short, J. C., \& Palmer, T. B. (2008). The application of DICTION to content analysis research in strategic management. Organizational Research Methods, 11, 727-752.

Short, J. C., Payne, G. T., Brigham, K., Lumpkin, G. T., \& Broberg, C. (2009). Family firms and entrepreneurial orientation in publicly traded firms: A comparative analysis of the S\&P 500. Family Business Review, 22, 9-24.

Short, J. C., Payne, G. T., \& Ketchen, D. J. (2008). Research on organizational configurations: Past accomplishments and future challenges. Journal of Management, 34, 1053-1079.

Sorenson, R. L. (1999). Conflict management strategies used by successful family businesses. Family Business Review, 12, 325-339.

Sorenson, R. L., Goodpaster, K. E., Hedberg, P. R., \& Yu, A. (2009). The family point of view, family social capital, and firm performance: An exploratory test. Family Business Review, 22, 239-253.

Stockmans, A., Lybaert, N., \& Voordeckers, W. (2010). Socioeconomic wealth and earnings management in private family firms. Family Business Review, 23, 280-294.

Tagiuri, R., \& Davis, J. A. (1992). On the goals of successful family companies. Family Business Review, 5, 43-62.

Tompkins, R. (2010). The organizational identity of a family business: The role of hybrid identity in organizational events (Unpublished doctoral dissertation). George Washington University, Washington, DC.

Tuggle, C. S., Schnatterly, K., \& Johnson, R. A. (2010). Attention patterns in the boardroom: How board composition and processes affect discussion of entrepreneurial issues. Academy of Management Journal, 53, 550-571.

Venkatraman, N., \& Ramanujam, V. (1986). Measurement of business performance in strategy research: A comparison of approaches. Academy of Management Review, 11, 801-814.

Walker, H. J., Field, H. S., Giles, W. F., Bernerth, J. B., \& Short, J. C. (2011). So what do you think of the organization? A contextual priming explanation for recruitment Web 
site characteristics as antecedents of job seekers' organizational image perceptions. Organizational Behavior and Human Decision Processes, 114, 165-178. doi:10.1016/j. obhdp.2010.11.004

Wall, T. D., Michie, J., Patterson, M., Wood, S. J., Sheehan, M., Clegg, C. W., \& West, M. (2004). On the validity of subjective measures of company performance. Personnel Psychology, 57, 95-118.

Ward, J. L. (1987). Keeping the family business healthy: How to plan for your continuing growth, profitability, and family leadership. San Francisco, CA: Jossey-Bass.

Weber, R. P. (1990). Basic content analysis. Newbury Park, CA: SAGE.

Westhead, P., \& Howorth, C. (2006). Ownership and management issues associated with family firm performance and company objectives. Family Business Review, 19, 301-316.

Zachary, M. A., McKenny, A. F., Short, J. C., Davis, K. M., \& Wu, D. (2011). Franchise branding: An organizational identity perspective. Journal of the Academy of Marketing Science. Advance online publication. doi:10.1007/s11747011-0252-7

Zachary, M. A., McKenny, A. F., Short, J. C., \& Payne, G. T. (2011). Family business and market orientation: Construct validation and comparative analysis. Family Business Review. Advance online publication. doi:10.1177/ 0894486510396871

Zellweger, T. M., \& Nason, R. S. (2008). A stakeholder perspective on family firm performance. Family Business Review, 21, 203-216.

\section{Bios}

Aaron F. McKenny is a doctoral student in the division of management and entrepreneurship at the University of Oklahoma. His current research interests center on the intersection of strategic management and entrepreneurship. His research can be found in Family Business Review, the Journal of the Academy of Marketing Science, and Business Horizons.

Jeremy C. Short is the Rath Chair in Strategic Management at the University of Oklahoma. His research focuses on multilevel determinants of firm performance, strategic decision processes, entrepreneurship, and research methods. $\mathrm{He}$ is an associate editor for the Journal of Management and for Family Business Review, and he serves on the review boards for Journal of Business Venturing and Organizational Research Methods. His research has appeared in a number of journals, including the Strategic Entrepreneurship Journal, Strategic Management Journal, Organization Science, Organizational Research Methods, Organizational Behavior and Human Decision Processes, Journal of Management, Personnel Psychology, Academy of Management Learning and Education, Journal of Management Education, Business Ethics Quarterly, and Family Business Review, among others.

Miles A. Zachary is a doctoral student in the area of management in the Rawls College of Business at Texas Tech University. His research interests include firm-level entrepreneurship, strategic management, and organizational issues of time and complexity. He has also published scholarly works in Family Business Review, Journal of the Academy of Marketing Science, Business Horizons, Journal of the Academy of Business and Economics, Journal of International Business, and Cultural Studies.

G. Tyge Payne is an associate professor of strategic management and holder of the Jerry S. Rawls Endowed Professorship of Management at Texas Tech University. His research interests include organization-environment fit/misfit, interorganizational relationships, social capital, firm-level entrepreneurship, and venture capitalism. He has authored or coauthored numerous publications appearing in outlets such as Business Ethics Quarterly, Entrepreneurship Theory and Practice, Family Business Review, Health Care Management Review, Journal of Business Ethics, Journal of Management, Journal of Management Studies, Journal of Small Business Management, and Organization Science, among others. He also currently serves on the governing board of the Southern Management Association and as a review board member for the Journal of Small Business Management and Journal of Management. 